\title{
EVALUATION OF CUSTOMER SATISFACTION WITH DIFFERENT SERVICE ENCOUNTERS: A STUDY ON SOME SELECTED SUPER SHOPS OF DHAKA CITY
}

\author{
Fatema Akter \\ Department of Marketing \\ National University, Bangladesh \\ bonnadu156@yahoo.com \\ Md.Nahid Mia \\ Department of Management \\ National University, Bangladesh \\ mohammadnahid_87@yahoo.com
}

\begin{abstract}
Customer is the king for any business whether it is manufacturing or service oriented in nature. Service encounter satisfaction is exigent to develop long run competitive position in market. The main objective of this study is to measure how different service encounters contribute on customer satisfaction by basing on some selected super shops of Dhaka city. The study has also focused on identifying the stages where customers are mostly satisfied from service encounter. This is a quantitative study where both primary and secondary data has used. The customers who purchase frequently from super shop are considered as population. The sample size of the study $i$ is 110 which has found by applying the Cochran's formula $\left(n_{0}=\left(Z^{2} p q\right) / e^{2}\right)$. Here, the degree of error has considered as $9.5 \%$. The respondents were determined purposively in order to collect primary data through questionnaire. The questionnaire has been prepared according to Rensis Likert 5 point scale. SPSS version-23 has been used to analyze the primary data. Descriptive statistical tools e.g. mean, standard deviation, standard error mean etc. have been used to analysis the primary data. Though the nature of the primary data is continuous and data has been collected from one sample group, so one tail t-test has been used to test the hypothesis. The study reveals that, the customer satisfaction of super shops varies at different stages. Customers are satisfied on the service encounter of pre-shopping stage, core shopping stage nevertheless they are not satisfied regarding the post service encounter. In order to retain the growing market potential, the super shop authorities need to concentrate on the customer satisfaction requirements at post-service encounter.
\end{abstract}

Keywords: Customer satisfaction; Service encounter; Super shop 


\section{Introduction}

Nowaday's super shop is a popular concept in Bangladesh, especially in city and divisional areas. Super shops introduced a whole new window in the shopping of daily necessities. These shops offer quality products at a stable price in safe and clean environment. It is now a growing version of retail business in city area. There are number of reasons of the popularity of this form of business. Among them busiest life style, increase of the duel career couple, high living cost, excessive traffic jam, quality of the service, increase of income and consciousness of the customers, quality products, product variety and special products, locations, hygienic environment, hassle free shopping, competitive price, service and layout of the shops etc. are mainly influencing factors for expanding this form of this business (Mahmud, 2018). Basically, the customers of super shops are comparatively higher income group people of the society. So, they want quality products and services rather than traditional shopping places. Along with the quality products, the customers also want to minimize their time and hazards for shopping.

\section{History of Super Shops in Bangladesh}

The history of retail super shop of Bangladesh is not too old. It has started in the year 2001. Agora is the first retail store in Bangladesh who operates as a chain of hypermarkets, discount department stores and grocery stores. After the breakthrough made by the pioneering Rahimafrooz Group, more than 120 super shops outlets have been set up in Bangladesh by around 40 companies over last 16 years. The industry is mainly dominated by three major players. These are Shwapno who has 59 outlets, Agora with 13 outlets and Meena Bazar with 18 outlets. Due to rapid urbanization, the industry is expected to grow by almost 15 times than its current size by 2014 (Kabir, 2015).

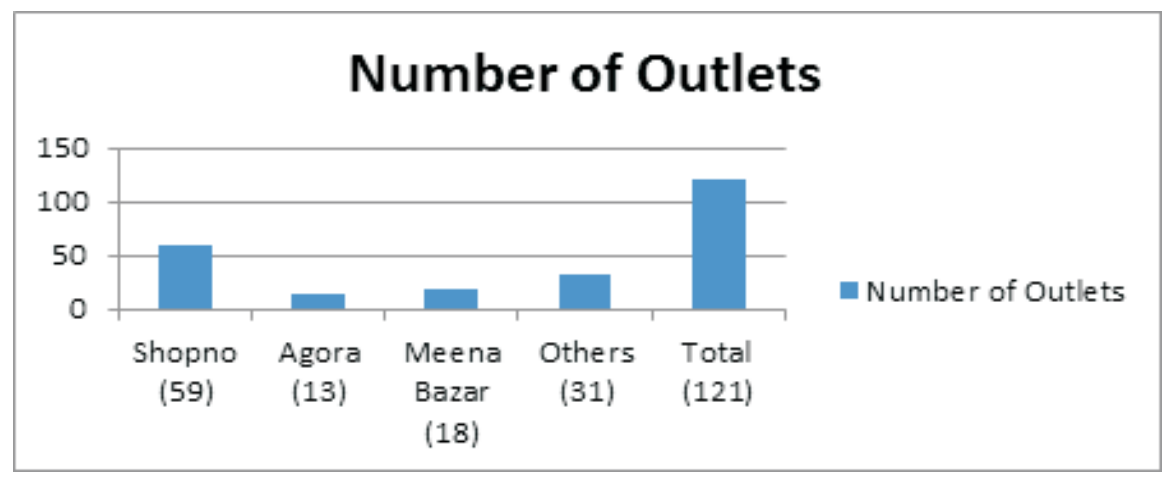

Figure 1: Total Super Stores Working in Bangladesh 
The main obstacle in the expansion of super shop is the supply chain. The distribution system is still not well organized. As a result, the goods are not delivered to the shops on time. Moreover, still it is time consuming to get the necessary permissions to open the super shop. Sometimes it requires a year or more. It also requires dealing with distributors and suppliers, some of whom are unprofessional. Bachmann (2008) shows in his writings that a majority of Bangladeshi customers will not change their shopping habits any time soon. The costs of opening up a single superstore in Bangladesh are at least four times as much as those of neighboring countries. The Bangladesh Super Shop Owners Association (BSOA) identified three major challenges for the superstore business in Bangladesh. The challenges include opening up a new mall and its forced shut down, uneven VAT scenario in the market and harassment in the name of food safety (Mala, 2018).

Organized retail is booming and creating huge opportunities for enterprises. Retailers though sell other companies' products work out their own marketing strategies fixing their own target market towards providing customer satisfaction separately. Retail stores, irrespective of product line and relative prices emerge in all shape and sizes, such as Specialty stores, Department stores, Supermarkets, Superstore, Convenience stores, Discount stores and off- price stores (Armstrong, et. al., 2006).

\section{Service Encounter}

A service encounter is a period of time during which customer interact directly with a service. It is also called as "Moment of Truth". A moment of truth is usually defined as an instance where the customer and the organization come into contact with one another in a manner that gives the customer an opportunity to either form or change an impression about the firm. Many services especially those classified as high contact involve numerous encounters between customers and service employees, either in person or remotely by phone or e-mail. Service encounters may also take place between customers and physical facilities or equipment. In low-contact services, customers are having more and more encounters with automated machines that are designed to replace human personnel. Customer interaction may provide two types of outcome like Moments of Magic and Moment of Misery. Favorable moments of truth have been termed as 'moments of magic'. These are instances where the customer has been served in a manner that exceeds his expectations through better services. On the other hand, Moment of Misery represents the situation where the customer interaction has a negative outcome due to poor customer services. 
A positive service encounter is definitely essential in competitive market to attract and retained the customer with the business. It provides distinctive positions over the rivals in a competitive market. So, every business should focus on its service encounter. Moreover, in today's increasingly service driven markets and with the proliferation of multiple providers for every type of product or service, moments of truth have become an important fact of customer interaction that marketers need to keep in mind while designing services. Durvasula et. al., (2005) reveals in their research work that two important determinants of service satisfaction i.e. service quality and service encounter. Service encounter is representing the interaction between the customer and the service provider. Further, it has been demonstrated that service quality is also related to customer perceptions of the service encounter. The authors of the study shows that the relationship between service quality and service satisfaction is not direct, but it is defined or mediated by customer perceptions of service encounters.

\section{Customer Experience}

Customer service experience is the sentiment associated with a company's ability to provide positive experiences to their customers. Services range from one-on-one interactions where a support agent resolves a customer issue, to exchanges with the brand on a more public scale. In commerce, customer experience is the product of an interaction between an organization and a customer over the duration of their relationship. This interaction is made up of three parts i.e.

i. The customer journey;

ii. The brand touch points through which the customer interacts;

iii. The environments that the customer experiences (including digital environment) during their experience.

A good customer experience means that the individual's experience during all points of contact matches the individual's expectations (Thompson, et. al., 2004).

Service encounter is any discrete interaction between the customer and the service provider relevant to a core service offering including the interaction involving provision of the core service offering itself. This interaction between customer and service provider can be occurred at 3 stages. Voorhees, et. al., (2017) presents a framework in their research work to guide comprehensive service experience. They defined pre-core service encounter, core service encounter and post-core service encounter. These stages are showing bellow with table 1; 
Table 1: Framework of Service Encounter through Service Experience

\begin{tabular}{|c|c|c|}
\hline Pre-Core Service Encounter & Core Service Encounter & Post-Core Service Encounter \\
\hline $\begin{array}{l}\text { Communication } \\
\text { Information Search } \\
\text { Access to Competitor Websites } \\
\text { Access to Third Party Websites } \\
\text { Offline Online Recommendations } \\
\text { Initial Contact } \\
\text { Face to Face } \\
\text { Telephone } \\
\text { Internet } \\
\text { On broading Activities }\end{array}$ & $\begin{array}{l}\text { Core Interaction } \\
\text { Employees } \\
\text { Other Customers } \\
\text { Technology } \\
\text { Environment }\end{array}$ & $\begin{array}{l}\text { Service Recovery Efforts } \\
\text { Customer Feedback } \\
\text { Post transaction surveys } \\
\text { Reviews } \\
\text { Crowd sourcing for new } \\
\text { service Development } \\
\text { Recommendation }\end{array}$ \\
\hline & Service Experience & \\
\hline
\end{tabular}

Pre-core service encounter period as the time interval preceding the core service encounters that focuses on leading customers to engage with the firm in the coreservice encounter. This period may encompass multiple service encounter (Bitner, 1995). The post-core service encounter period is defined as the time interval following the core service encounter during which consumers assesses and act on their experience in the two previous periods. Through this period, the firm's goal is to retain customers and to improve future service experiences.

\section{Service Encounter in Super Shop Services in Bangladesh}

Like any other service industry, it is vital to measure the service encounter in super shops services. Though today's marketers are more conscious about customer needs, wants and demands than that of past but still the service provides by the marketer are less smart than any other neighboring countries. Bangladeshi super shops are using different types of available digital devices to connect the lost, current and prospective customers. People of the country, especially in the city areas are becoming more engaged with the super shops due to different reasons like quality products, less time consuming, better customer service, availability of different types of products under an umbrella etc. Today's customers are also smarter than the past. They are now becoming a strategic partner of the service provider. As a result, they always focus on

Journal of Business Studies, 7(2) - 05 -


the changes made by the organizations. They always become connected with the service provider so that the service provider can explore the expectations of the customers. Companies are also investing more in maintaining the relationship with the customers at different stages of services. The both parties interactions make the service industries smarter than that of past.

\section{Literature Review}

\subsection{Service encounter}

Service encounter is the face-to-face interactive relation between service provider and service recipient during the process of service consumption. It is also considered as the core of service marketing having considerable impact on service quality control, service delivery systems and customer satisfaction etc. (Dolen, et. al., 2002). Moreover, the service encounter perspectives mentioned here as an important criteria or attributes against which customers assess or evaluate service providers (Roth, 1997). The concept of these service encounter attributes is highly similar to some perspectives of service quality (Winsted, 1993). Physical environment is usually one of the significant factor affecting consumers' ultimate satisfaction with a service. The physical environment may help or hinder the achievement of internal organizational objectives and external marketing objectives. For consumers, evaluation of a service firm often depends on evaluation of the service encounter or the period of time when the customer interacts directly with the firm. Researchers need to consider simultaneously all periods of the service experience to make valuable contributions to the literature (Voorhees, 2017).

\subsection{Services marketing mix}

The marketing mix is defined as the controllable variables that an organization can coordinate to satisfy its target market (McCarthy, 1987). Because of the distinguishing characteristics of services, it has been suggested that service firms have additional variables, beyond the traditional "four P's" that can satisfy target markets (Gronroos, 1984). Booms et. al., (1981) proposed an expanded marketing mix for services consisting of the four traditional elements like product, price, place, promotion and three new ones such as physical evidence (the physical surroundings and all tangible cues), participants (all human actors in the service encounter including firm personnel and other customers) and process including procedures, mechanisms and flow of activities. There are three key players in marketing exchange relationships. These are 
the company, the customer and the employee. The three players can be depicted as vertices in a triangular framework (currently referred to the literature as the "triangle model of services marketing" with three possible dyadic links (Kotler, 1994).

\subsection{Customer satisfaction}

Since the 1970s researchers have focused on understanding consumer satisfaction. Customer satisfaction is widely recognized as a key pressure in the information of customers future purchase intentions. Satisfied customers are also likely to tell others favorable experience and thus engage in positive work of mouth advertising (Karmugil, et. al., 2015). Organized retailers need to enhance customer satisfaction in terms of ensuring product quality, store convenience, after sales services, availability of new products and lure buyers with attractive promotional schemes (Malik, 2012). Attaining high level of customer satisfaction is extremely significant to any business. A satisfied customer is most likely to be loyal and to make repeat orders. Customer satisfaction is an asset that should be monitored and managed just like any physical asset (Jeevananda, 2011). Two key elements of service satisfaction for customers are the perception that they have at least some control or choice and that the service provider is being fair (Namasivayam, 2003). Yazdanpanah et. al., (2013) presents in their quantitative study that employees friendliness and competence dimension have the highest priority and the employees civility dimension has the lowest priority where professionalism dimension have $2.9 \%$, civility dimension have $1.6 \%$, friendliness dimension have $5.5 \%$, competence dimension have $5.5 \%$ relative weights. The findings of research show that there is a relationship between service encounter quality dimensions and Customer Satisfaction. Jayawardhena, (2010) has conducted a factor analysis to justify a conceptual model which was developed through literature review. He has shown that the service encounter quality is directly related to customer satisfaction and service quality perceptions. The research offers insights into the specific of business-to-business service dynamics by examining the role of service quality, satisfaction, value on loyalty to both employees of the firm and the firm itself.

\subsection{Customer retention}

Customer retention has received considerable attention. It has become a prime issue for food retail organizations desiring to stay in business, increase footfall, maximize profits or build and sustain the competitive advantage in the food sector. CRM can play a vital role for retaining the customers. The top management needs to be 
conscious about maintaining the relationships which will help to retain the customers (Mia, 2018).

\subsection{Research gap}

The above literature review shows that, a number of research works available about measuring the customer satisfaction focusing on different sectors. A customer can be benefited from three stages of service like pre, during and post shopping stage. Most of the organizations focus only at during stage to satisfy customers. In order to retain the customers, the satisfaction from pre and post shopping stage also plays a crucial role. This study has conducted focusing the three stages to know about the customer service encounter satisfaction. If company can concentrate on the service encounter satisfaction by considering the customer needs of each stages, this may help to attract more the customers. The above literature review shows that, number of research work have conducted by different scholars to measure the customer satisfaction focusing only on product/ service features. As a result, along with the satisfaction from product or service, it is also significant to measure the service encounter satisfaction at different stages.

\section{Objectives of the Study}

The main objective of the study is to measure how different service encounter contributes on customer satisfaction. Along with main objectives, the study will also meet the following supportive objectives;

- To identify the encounters which will mostly contribute on customer satisfaction;

- To identify the limitations in service encounter to satisfy the customers;

\section{Hypotheses of the Study}

The study has been conducted basing on the following hypotheses;

H1: The customers of super shop are satisfied in the pre-service encounter stage.

H2: The customers of super shop are satisfied in during shopping stage.

H3: The customers of super shop are satisfied in the post-service encounter stage.

\section{Methodology of the Study}

\subsection{Nature of the study}

This study is mainly quantitative in nature to measure the customer service encounter satisfaction basing on primary data. 


\subsection{Studyarea}

The area of the study is Dhaka city. Primary data has been collected from the customers directly through close ended questionnaire. Here customers mean who shop frequently from different super shops of Dhaka city.

\subsection{Population, sample design and size}

In this study, the customers who purchase from the super shop are considered as population. The sample size of the study is 110 which has found by applying the Cochran's formula. The process of sample size determination is presented below;

$$
\begin{aligned}
& n_{0}=\frac{Z^{2} p q}{e^{2}} \\
& =\frac{1.96^{2} * 0.5 * 0.5}{0.095^{2}} \\
& =106.42 \\
& \text { Where } \\
& \checkmark e \text { means the margin of error which is assumed as } 9.5 \% \\
& \text { or } 0.095 \text {; } \\
& \checkmark \quad \mathrm{p} \text { is the (estimated) proportion of the population which } \\
& \text { has the attribute in question is } 50 \% \text { or } 0.5 \text {, } \\
& \text { So, } \quad 110 \quad \text { is } \\
& \text { considered as } \\
& \checkmark \mathrm{q} \text { is } 1-\mathrm{p} \text { or } 1-0.5 \text { or } 0.5 \text {. } \\
& \text { sample } \\
& \checkmark \mathrm{Z} \text { value at the } 95 \% \text { confidence level is } 1.96
\end{aligned}
$$

In order to collect primary data, the respondent has been determined purposively from the population.

\subsection{Data collection methods}

In this study, both primary and secondary data has been used. Primary data has been collected from the respondents through questionnaire. Secondary data has been collected through studying different articles, journals, newspapers, websites, books.

\subsection{Questionnaire}

The questionnaire has been prepared according to Rensis Likert 5 point scale. The five points are strongly satisfied, satisfied, neutral, dissatisfied and strongly dissatisfied. These 5 points are converted with numerical values respectively 5,4,3,2 and 1 for analysis.

\subsection{Analysis of the collected data}

The collected data has analyzed with Statistical Package for the Social Sciences (SPSS) version-23. Descriptive statistics including mean, standard deviation, standard error mean etc. have conducted to analyze the primary data. Though the 
nature of the data is continuous in nature and data has collected from one sample group, so one tail t- test has been used to test the hypothesis. Here, the test level is considered as 3 and the confidence level is considered as 95\% level of significance.

\section{Limitations of the Study}

The study has been conducted basing on the super shop operating in Dhaka city to analyze the customer service encounter satisfaction. A good number of super shops are available in the city in order to meet the growing demand of customers. The primary data has been collected from the users of these shops from different super shop. The research findings would be more accurate if the study can be conducted by basing on the customers of specific institution. On the other hand, the sample size of the study is too small. This is because of the consideration of degree of error. Here, the degree of error has assumed as $9.5 \%$. If the degree of error can be considered as $5 \%$, than the sample size will be more acceptable. On the other hand, the sample respondents have collected from the users of Dhaka city only. The research work may provide more appropriate findings, if data can be collected from the other cities. However, along with the above limitations, the research findings will be a good guideline provider for the future researchers, policy makers, owners, customers and other concerned parties of super shops. If the super shops authority can redesign their services by exploring the gap of customer service encounter at each stage, the customer will be benefited with an excellent service. This initiative will help to organization to retain their customers in a competitive market.

\section{Conceptual Framework}

A customer needs to interact with service provider at different stages in order to get the service. Service encounter is a period of time during which a consumer directly interacts with a service provider. Service encounter is the dyadic interaction between a customer and service provider (Surprenant, 1987). Number of factors involved for the service encounter satisfaction of customers. Here below, a framework is given which presents the factors; 
Table 2: Factors affecting Customer Service Encounter Satisfaction

Factors related to

Pre-Encounter Stage

Satisfaction

$\checkmark$ Easy mode of communication;

$\checkmark$ Adequate number of service provide;

$\checkmark$ Adequate information about stores;

$\checkmark$ Use of digital devices for communication;

Available reliable sources

of information about stores;
Customer

Service

Encounter

Satisfaction

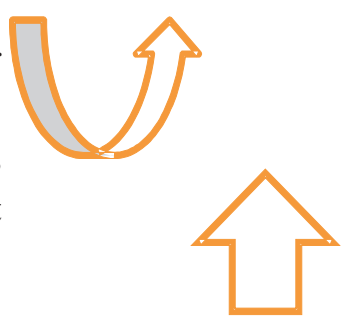

Factors related to

During Encounter Satisfaction

$\checkmark \quad$ Comfortable shopping environment;

Available sufficient skilled and helpful sales representatives;

Adequate technical devices in shopping stores;

$\checkmark \quad$ Quick, easy and transparent billing systems;

$\checkmark \quad$ Less time consuming shopping;

$\checkmark \quad$ Hassle free shopping environment;

Factors related to

Post-Encounter Stage Satisfaction

$\checkmark$ Adequate service recovery efforts

$\checkmark$ Customer feedback systems

$\checkmark$ Positive attitude regarding customers review

$\checkmark$ Available Complain Management Systems (CMS)

$\checkmark$ Satisfactory post-service interactions

Source: Researcher's Proposed Framework

\section{Analysis and Findings}

The analysis of the collected primary data is presenting below;

\section{Descriptive Statistics}

Table 3: Customers Satisfaction on the Pre-core Service Encounter

\begin{tabular}{|l|c|c|c|c|}
\hline \multicolumn{1}{|c|}{ Particulars } & N & Mean & Std. Error & SD \\
\hline Super Shop ensures easy communication process & 110 & 3.71 & 0.088 & 0.929 \\
\hline Adequate customer service providers & 110 & 3.64 & 0.096 & 1.009 \\
\hline Customers get necessary information in stores & 110 & 3.40 & 0.076 & 0.804 \\
\hline Customers get necessary information via phone calls, online & 110 & 3.00 & 0.107 & 1.125 \\
\hline Adequate sources to get reliable information & 110 & 3.43 & 0.291 & 3.054 \\
\hline
\end{tabular}

Journal of Business Studies, 7(2)

$-11-$

2020 
The above table shows the mean value of customers' satisfaction on the pre-core service encounters stage. The table shows that the customer response on "super shop ensures easy communication process" is higher (mean $=3.71, \mathrm{SD}=0.929$ ) among the five variable where the mean value of customers response on "Customers get necessary information via phone calls, online" is lower (mean=3.00, $\mathrm{SD}=1.125)$. The table also shows that, the customers' response for all variables is greater than average value 3.00 which indicates that customers are satisfied about pre-core service encounter stage.

Table 4: Customers Satisfaction on the Service Encounter of core stage

\begin{tabular}{|l|c|c|c|c|}
\hline \multicolumn{1}{|c|}{ Particulars } & N & Mean & Std. Error & SD \\
\hline Comfortable and satisfactory Shopping environment & 110 & 4.07 & 0.074 & 0.786 \\
\hline Available helpful sales persons for quick shopping & 110 & 3.55 & 0.095 & 1.000 \\
\hline Superstores have adequate technical devices to easy access & 110 & 3.35 & 0.101 & 1.063 \\
\hline Quick, easy and transparent billing systems & 110 & 3.45 & 0.087 & 0.915 \\
\hline Less time consuming shopping & 110 & 3.67 & 0.090 & 0.949 \\
\hline Hassle free shopping & 110 & 3.71 & 0.105 & 1.109 \\
\hline
\end{tabular}

The above table shows the mean value of customers' responses on the service encounter of core stage. The table shows that the response on "Comfortable and satisfactory shopping environment" is higher (mean=4.07, $\mathrm{SD}=0.786$ ) among the five variable where the mean value of customers response on "superstores have adequate technical devices to easy access" is lower (mean $=3.35, \mathrm{SD}=0.101$ ). The table also shows that, the customers' response for all variables is higher than average value 3.00 which indicates that customers are satisfied about service encounter at during shopping or core stage.

Table 5: Customers Satisfaction on the Post Service Encounter Stage

\begin{tabular}{|l|c|c|c|c|}
\hline \multicolumn{1}{|c|}{ Particulars } & N & Mean & Std. Error & SD \\
\hline Adequate service recovery efforts & 109 & 3.10 & 0.070 & 0.744 \\
\hline Have customer feedback systems & 110 & 2.74 & 0.089 & 0.942 \\
\hline $\begin{array}{l}\text { Customer reviews and recommendations are appreciated } \\
\text { positively }\end{array}$ & 110 & 2.54 & 0.088 & 0.925 \\
\hline Have complaint management Systems & 110 & 2.82 & 0.085 & 0.897 \\
\hline Post-Service Interactions are satisfactory & 110 & 2.88 & 0.076 & 0.798 \\
\hline
\end{tabular}


The above table shows the mean value of customer' responses on the post service encounter satisfaction. The table shows the perceptions on "adequate service recovery efforts" is greater (mean=3.10, $\mathrm{SD}=0.741$ ) among the five variable where the mean value of customers perceptions on "customer reviews and recommendations are appreciated positively" is lower (mean $=2.54, \mathrm{SD}=0.925$ ). The table also shows that, the customers' response for all variables is lower than average value 3.00 except "adequate service recovery efforts" which indicates that customers are not satisfied about post service encounter.

Table 6: Survey Data

\begin{tabular}{|c|c|c|c|c|}
\hline \multicolumn{5}{|c|}{ One-Sample Statistics } \\
\hline Hypotheses & $\mathrm{N}$ & Mean & SD & Std. Error Mean \\
\hline $\begin{array}{l}\text { The customers of super shop are satisfied } \\
\text { on pre-core service encounter stage. }\end{array}$ & 110 & 3.44 & 0.778 & 0.074 \\
\hline $\begin{array}{l}\text { The customers of super shop are satisfied } \\
\text { on during shopping stage. }\end{array}$ & 110 & 3.63 & 0.671 & 0.064 \\
\hline $\begin{array}{l}\text { The customers of super shop are satisfied } \\
\text { on post-service encounter stage. }\end{array}$ & 110 & 2.82 & 0.606 & 0.057 \\
\hline
\end{tabular}

\section{Table 7: Survey Data}

\begin{tabular}{|l|c|c|c|c|c|c|}
\hline \multicolumn{7}{|c|}{ One-Sample Test } \\
\hline \multirow{2}{*}{ Hypotheses } & \multicolumn{7}{|c|}{ Test Value $=3$} \\
\cline { 5 - 8 } & & & $\mathrm{p}$ & $\begin{array}{c}\text { Mean } \\
\text { valu }\end{array}$ & \multicolumn{2}{c|}{$\begin{array}{c}95 \% \text { Confidence } \\
\text { Level }\end{array}$} \\
\cline { 5 - 8 } & $\mathrm{T}$ & $\mathrm{df}$ & $\begin{array}{c}\text { value } \\
\text { Difference }\end{array}$ & Lower & Upper \\
\hline $\begin{array}{l}\text { The customers of super shop are satisfied } \\
\text { on pre-core service encounter stage. }\end{array}$ & 5.95 & 109 & .00 & 0.44182 & .294 & .588 \\
\hline $\begin{array}{l}\text { The customers of super shop are satisfied } \\
\text { on during shopping stage. }\end{array}$ & 9.95 & 109 & .00 & 0.63788 & .510 & .764 \\
\hline $\begin{array}{l}\text { The customers of super shop are satisfied } \\
\text { on post-service encounter stage. }\end{array}$ & -3.11 & 109 & .07 & -0.18000 & -.294 & -.065 \\
\hline
\end{tabular}

$*(\mathrm{p}=0.05)$ 
The table 6 shows that, the mean value of customer satisfaction on "Super shop's Precore Service Encounter is satisfactory to the customers" is 3.44 and the SD is 0.778. On the other hand, table 7 shows that $t$ value is 5.95 and the $p$ value is 0.00 . It represents that the hypothesis is accepted that is customers are satisfied about the pre-core service encounter of super shop's service. It is also noticeable that, the mean value of customer satisfaction on "Super shop's service encounter is satisfactory during shopping (core stage) to the customers" is 3.63 and the SD is 0.671 . On the other hand, table 7 shows that $t$ value is 9.95 and the $p$ value is 0.00 . It represents that the hypothesis is accepted that is customers are satisfied about the service encounter of super shop's service during shopping or core stage.

On the other hand, the mean value of customer satisfaction on "super shop's post service encounter is satisfactory to the customers" is 2.82 and the SD is 0.606 . However, table 7 shows that $t$ value is -3.113 and the $p$ value is 0.002 . It represents that the hypothesis is rejected. Customers are not satisfied about the post service encounter of super shop's service.

\section{Conclusions and Recommendations}

\subsection{Conclusions}

Every organization desires to satisfy its customer's need fully. Customer's needs are diversified because every customer is unique in terms of tastes, choice and habit. Due to different benefits, peoples are becoming dependent on super shops for daily household shopping. Especially the scenario is very common in city areas. Customers are getting better service and quality products with reasonable price from these super shops. However, with the quality products and services, the customers have also some implied needs from the super shops. The service provider requires satisfying the customers at three stages of services. This study has found that the customers of super shops are satisfied about the service of pre and core shopping stage nevertheless they are not satisfied about the post stage. Post service encounter stage is the best way to create customer loyalty. In the modern competitive business era, customer loyalty and retention is the foremost tool to sustain competitive advantage. This leads to profit maximization and cost reduction. Moreover, powerful word of mouth influence leads dramatic changes in brand equity of competitors. Different factors of post service stage such as service recovery efforts, customer feedback systems, customer review evaluation, complaint management and post-service interactions will create strong bondage between the service provider and customers which ultimately converts a 
customer into a loyal one. In order to customer retention and future sustainability, super shop authorities need to concentrate on the post stage needs of customers. Otherwise, the on growing dependency of customers towards the super shop may not be continued.

\subsection{Recommendations}

On the basis of the findings, the researchers suggest the following initiatives need to be taken by the authorities of super shops;

i. Super shops' authority should focus on creating long run relation with current and future or even lost customers. To build such relations, the authority may focus on post service encounter satisfaction to the customers. The authority should maintain post-service interactions satisfactory to the customers for making them future customers.

ii. Super shops' authority need to ensure feedback from the current customers about products/services. They also can develop complain management systems (CMS) which will handle the customers complain about the service.

iii. Super shops' authority can accept the customer reviews and recommendations positively. Modern digital mode i.e. face book, mail or even websites etc. can be used for the purpose. Efficient manpower can be appointed to handle the customer reviews and recommendations. The authority can also increase the use of phone calls, websites face book etc. to provide customers necessary information.

iv. The authority of superstores needs to ensure all types of technical devices at the stores available. This will help customers to protect the risk and hazard of bearing cash.

Journal of Business Studies, 7(2)

$-15-$ 


\section{References:}

Armstrong, G., \& Kotler, P., (2006). Marketing: An Introduction (8th ed.). Prentice Hill: New Jersey.

Bachmann, B. (2008). Supermarkets on the Rise. The Daily Star. Retrieved from https://www.thedailystar.net/news-detail-68728

Bitner, M. J. (1995). Building Service Relationships: It's All About Promises. Journal of the Academy of Marketing Science, 23(4), 241-251.

Booms, B. H. \& Bitner, M. J. (1981). Marketing Strategies and Organization Structures for Service Firms. Chicago: American Marketing Association, pp. 4752.

Dolen, M., Willemijn, V., \& Ruyter, K. (2002). Moderated Group Chat: An Empirical Assessment of a New E-service Encounter. International Journal of Service Industry Management, 13(5), 496-511.

Durvasula, S., Lysonski, S. \& Mehta, S. C., (2005). Service Encounters: The Missing Link between Service Quality Perceptions and Satisfaction. The Journal of Applied Business Research, 21(3), 15-26.

Gronroos \& Christian (1984). A Service Quality Model and Its Marketing Implications. European Journal of Marketing, 18(4), 36-44.

Jayawardhena, C. (2010). The Impact of Service Encounter Quality in Service Evaluation: Evidence from a Business-to-Business Context. Journal of Business \& Industrial Marketing, 25 (5), 338-348.

Jeevananda, S., (2011). Study on Customer Satisfaction Level at Hypermarkets in Indian Retail Industry. Research Journal of Social Science and Management, 1(3)

Kabir, A. (2015, February 16). Market Insight: Supermarket Industry in Bangladesh Part-1. LightCastle. Retrieved from https://www.lightcastlebd.com/ insights/2015/02/16/market-insight-supermarket industry-bangladesh 
Karmugil, S. \& Kannapa, R. (2015). A Study on Customer Satisfaction Towards Retail Stores in Tiruchirappalli Town. International Journal of Advanced Research in Management and Social Sciences, 4(6), 69-78.

Kotler, P. (1994). Marketing Management. Englewood Cliffs. New Jersey: Prentice Hall, Inc.

Mahmud, A. H., (2018, March 8). "Why more and more people are leaning towards superstores?" The Dhaka Tribune. Retrieved from: https://www.dhakatribune. com/business/2018/03/08/people-leaning-towards-superstores

Mala, D. A. (2018). Costs of Opening Superstores in Bangladesh Among Highest in the Region. The Financial Express. Retrieved from: https://thefinancialexpress. com.bd/trade/costs-of-opening-superstores-in-bd- among highest-in-the-region1532231559

Malik, M., (2012). A Study on Customer's Satisfaction Towards Service Quality of Organized Retail Stores in Haryana. Indian Journal of Marketing, 42(2), 51-60.

McCarthy, E. (1987). Basic Marketing (9th ed.). Jerome and William D. Perreault, Jr. IL: Richard D. Irwin, Inc. pp. 35.

Mia, M. N., (2018). Customer Relationship Management Practices in Private Medical Hospitals of Bangladesh. BUP Journal, 6(1), 110-126.

Namasivayam, K. \& Hinkin, T. R. (2003). The Customer's Role in the Service Encounter: The Effects of Control and Fairness. Cornell Hotel and Restaurant Administration Quarterly, 44(3), 26-36.

Roth, D., Lauber, B. G., Crane, R. D., \& Clark, J. A., (1997). Administrative Update: Impact of State Mental Health Reform on Patterns of Service Delivery. Community Mental Health Journal, 33(6), 473-486.

Surprenant, \& Michael R. S. (1987). Predictability and Personalization in the Service Encounter. Journal of Marketing, 51(1), 73-80.

Thompson, E. \& Kolsky, (2004, December 27). How to Approach Customer Experience Management.

Journal of Business Studies, 7(2)

$-17-$

2020 
Voorhees, C. M., Fombelle, P. W., Gregoire, Y., Bone, S., \& Gustafsson, A. (2017). Service Encounters, Experiences and the Customer Journey: De? ning the Field and a Call to Expand our Lens. Journal of Business Research, 1-12, 30(40), Retrieved from http://dx.doi.org/10.1016/j.jbusres.2017.04.014

Winsted, F. K. (1993). Service Encounters Dimensions: Across-cultural Analysis. Published Doctoral Dissertation, University of Colorado at Boulder.

Yazdanpanah, Y., Feizi, M. \& Abad, M. H. M. (2013). Relative importance of Service Encounter Quality dimensions and customer Satisfaction in Meshkin City's Mellat Banks. Arabian Journal of Business and Management Review (Nigerian Chapter), 1(7), 29-36. 